\title{
UPAYA MENINGKATKAN HASIL BELAJAR GULING DEPAN DALAM SENAM LANTAI DENGAN METODE BERMAIN PADA SISWA KELAS V SDN 1 KANCONG TANAH PINOH BARAT
}

\author{
Sahrol 1, Khairil Akbar', Nur Moh Kusuma Atmaja ${ }^{3}$ \\ ${ }^{1}$ Mahasiswa Penjaskesrek STKIP Melawi \\ ${ }^{2.3}$ Dosen Penjaskesrek STKIP Melawi \\ Jl. RSUD Melawi KM 04 Kec. Nanga Pinoh, Kab. Melawi Kalimantan Barat \\ Email:sahrolsarol61@gmail.com \\ khairilakbar89@gmail.com.atmajanur27@gmail.com
}

\begin{abstract}
This study aims to be a classroom action research (PTK). This study uses 2 cycles, where each cycle consists of: 1) planning: 2) implementation: 3) observation: 4) reflection. The research carried out included 3 domains, namely the cognitive, affective, and psychomotor domains. In addition, observations were made of the learning process during the research activities and made a questionnaire in the form of a questionnaire of interest and learning motivation, to determine the extent of student satisfaction and interest in participating in learning. by using the game method. It can be concluded that the front roll floor gymnastics learning through the three-post game has a positive effect, namely it can improve learning outcomes and student interest and motivation as indicated by the average student's answer who strongly agrees $100 \%$ on the student interest questionnaire agree $100 \%$ on the results of the student motivation questionnaire
\end{abstract}

\section{Keywords: Learning Outcomes, Front Roll, Playing Method}

\begin{abstract}
Abstrak: Penelitian ini bertujuan adalah penelitian tindakan kelas (PTK). Penelitian ini menggunakan 2 siklus, dimana masing-masing siklus terdiri atas: 1) perencanaan: 2) pelaksanaan: 3 ) pengamatan: 4) refleksi. Penelitian yang dilakukan mencakup 3 ranah yaitu ranah kognitif, ranah afektif, dan ranah psikomotorik.selain itu dilakukan pengamatan terhadap proses pembelajaran selama kegiatan penelitian berlangsung dan membuat angket kuisioner berupa angket minat dan motivasi pembelajaran, untuk mengetahui sejauh mana kepuasan dan ketertarikan siswa dalam mengikuti pembelajaran dengan menggunakan metode permainan. Dapat disimpulkan bahwa pembelajaran senam lantai guling depan melalui permainan tiga pos mempunyai pengaruh positif, yaitu dapat meningkatkan hasil belajar dan minat serta motivasi belajar siswa yang ditunjukan dengan rata-rata jawaban siswa yang menyatakan sangat setuju $100 \%$ pada angket minat siswa, dan siswa menjawab sangat setuju $100 \%$ pada hasil angket motivasi siswa
\end{abstract}

\section{Kata Kunci: Hasil Belajar, Guling Depan, Metode Bermain}

$\Lambda_{\text {bersifat fisik maupun mental (Sardiman }}^{\text {ktivitas belajar adalah aktivitas yang }}$

2006 : 101). Selama kegiatan belajar kedua

aktivitas itu harus selalu terkait. Sebagai

contoh seseorang itu sedang belajar dengan

membaca. Secara fisik kelihatan bahwa orang tadi membaca menghadapi suatu buku, tetapi mungkin pikiran dan sikap mentalnya tidak tertuju buku yang dibaca. Ini menunjukkan tidak ada keserasian antara aktivitas fisik dengan aktivitas mental. Kalau sudah demikian, maka belajar itu tidak akan 


\section{Jurnal Pendidikan Jasmani Kesehatan dan Rekreasi (Penjaskesrek) \\ Volume 8, Nomor 1, Januari 2021}

optimal. Begitu juga sebaliknya kalau yang aktif itu hanya mentalnya juga kurang bermanfaat. Misalnya ada seseorang berpikir tentang sesuatu, tetapi kalau tidak disertai perbuatan atau aktivitas fisik misalnya dituangkan pada tulisan atau disampaikan kepada orang lain, juga pemikiran tadi tidak ada gunanya.

Sardiman (2006:101) membuat suatu daftar yang berisi 177 macam kegiatan siswa yang antara lain dapat digolongkan menjadi visual activities, oral activities listening activities, writing activities, drawing activities, motor activities, mental activities, emotional activities.

Diskusi bila mengacu pada Diedrich dapat mengukur aktivitas siswa berupa:

a. Oral aktivities (kemampuan siswa dalam mengajukan pertanyaan, kemampuan siswa dalam menjawan pertanyaan, kemampuan siswa dalam mengemukakan pendapat, dan kemampuan siswa dalam mempresentasikan hasil diskusi),

b. Mental activities (kemampuan siswa dalam menemukan jawaban sendiri, ketepatan siswa dalam menarik kesimpulan),

c. Emotional activities (kesiapan siswa sebelum mengikuti pembelajaran, kerapian siswa, keaktifan siswa, sikap siswa terhadap teman yang membutuhkan bantuan, tanggung jawab siswa dan melakukan aktivitas lain yang tidak mendukung proses pembelajaran).

Nasution (2004 : 100) menyatakan bahwa salah satu ciri terpenting terjadinya proses belajar adalah ditandai dengan adanya aktivitas siswa. Aktivitas siswa dalam belajar tidak hanya mendengarkan dan mencatat, hendaknya mencakup aktivitas yang bersifat fisik (jasmani) dan mental (rohani). Menurut Paul B. Diedrich dalam Nasution. S (2004:9) menyatakan ada 177 macam kegiatan siswa dalam belajar yang antara lain dapat digolongkan sebagai berikut;

1. Visual activities, aktivitas yang termasuk didalamnya misalnya membaca, memperhatikan gambar, demonstrasi maupun percobaan atau pekerjaan orang lain.

2. Oral activities, seperti menyatakan, merumuskan, bertanya, memberi saran, mengeluarkan pendapat, mengadakan wawancara, diskusi, dan interupsi.

3. Listening activities, sebagai contoh yaitu mendengarkan uraian, percakapan, diskusi, dan interupsi.

4. Writing activities, seperti menulis cerita, karangan, laporan, angket, dan menyalin.

5. Drawing activities, misalnya menggambar, membuat grafik, peta, dan diagram. 


\section{Jurnal Pendidikan Jasmani Kesehatan dan Rekreasi (Penjaskesrek) \\ Volume 8, Nomor 1, Januari 2021}

6. Motor activities, yang termasuk didalamnya yaitu melakukan percobaan, membuat konstruksi, bermain, berkebun, dan berternak.

7. Mental activities, misalnya mengingat, memecahkan soal, menganalisis, membuat hubungan, dan mengambil keputusan.

8. Emotional activities, misalnya menaruh minat, gembira, bersemangat, berani, tenang, dan gugur.

Keterlibatan siswa dalam kegiatan belajar dengan berbagai aktivitas yang telah diuraikan, akan menciptakan suasana belajar yang tidak membosankan, dan nantinya akan mempengaruhi hasil belajar siswa. Anni (2004:10) menyatakan bahwa hasil belajar merupakan perubahan perilaku yang diperoleh pembelajar yaitu siswa setelah mengalami aktivitas belajar. Hasil belajar adalah kemampuan-kemampuan yang dimiliki siswa setelah siswa menerima pengalaman belajarnya (Sudjana 2004:22).

Perolehan aspek-aspek perubahan perilaku tersebut tergantung pada apa yang dipelajari oleh siswa. Dalam pembelajaran, perubahan perilaku yang harus dicapai oleh siswa setelah melaksanakan aktivitas belajar dirumuskan dalam tujuan pembelajaran.
Hasil belajar merupakan perubahan perilaku yang diperoleh pembelajaran setelah mengalami aktifitas belajar (Chatarina Tri Anni, dkk, 2007:5). Hasil belajar merupakan faktor yang sangat penting, karena hasil belajar mencerminkan kemampuan siswa dalam mempelajari suatu mata pelajaran. Bentuk dari hasil belajar biasanya ditunjukan dengan nilai yang diberikan guru.

Seperti yang diungkapkan oleh Nana Sudjana (2009:85) bahwa hasil belajar merupakan perubahan perilaku yang diperoleh siswa setelah mengalami kegiatan belajar. Perolehan aspek-aspek perubahan perilaku tersebut bergantung pada apa yang dipelajari oleh siswa, oleh karena itu, apabila siswa mempelajari pengetahuan tentang konsep, maka perubahan perilaku yang diperoleh adalah berupa penguasaan konsep.

Dari pengertian-pengertian diatas, dapat disimpulkan bahwa hasil belajar perubahan perilaku siswa dari tidak tahu menjadi tahu, dan dari tidak mengerti menjadi mengerti yang diukur menggunakan teknik penilaian tertentu setelah mengalami kegiatan belajar.

\section{METODE PENELITIAN}


Penelitian ini menggunakan rancangan penelitian tindakan kelas (Classroom action research) dengan mengunakan siklus tindakan. Pada penelitian tindakan ini, mengunakan model yang dijelaskan (Zainal Aqib, 2006) ) yaitu: 1) Rencana (planning) 2)Tindakan (Aktion) 3) Pengamatan (Obflervation) dan 4) Refleksi (Reflection). Subjek penelitian tindakan kelas ini adalah siswa kelas V SDN 1 Kancong Tanah Pinoh Barat yang terdiri dari 23 siswa dengan komposisi laki-laki 13 orang dan perempuan 10 orang.

\section{HASIL DAN PEMBAHASAN}

Pelaksanaan penelian tindakan kelas ini dilakukan dalam dua siklus, siklus I dan siklus II, ketuntasan hasil belajar siswa melalui hasil penelitian ini menunjukan bahwa pembelajaran pertemuan terbimbing memiliki dampak positif dalam meningkatkan prestasi belajar siswa. Hal ini dapat terlihat dan semakin mantapnya pemahamam siswa terhadap materi yang disampaikan peneliti/kolaborator (ketuntasan belajar meningkat dari siklus I dan siklus II). Pada siklus I ketuntasan belajar mencapai $32,5 \%$ sedangkan pada siklus I ketuntasan hasil belajar siklus II menjadi 99\%. Hal ini menunjukan adanya peningkatan hasil belajar siswa sebesar $90,83 \%$.

$$
\text { Sedangkan untuk proses }
$$
pembelajaran berdasarkan analisis data diperoleh bahwa aktifitas siswa selama proses belajar siswa yaitu dapat ditunjukan dengan permainan tiga pos dalam setiap siklus mengalami peningkatan. Hal ini berdampak positif terhadap prestasi belajar siswa yaitu dapat ditunjukan dengan meningkatnya nilai rata-rata setiap siklus yang terus meningkat. Dalam proses belajar mengajar siswa terlihat semangat, mendengarkan/memperhatikan

penjelasan guru, melakukan kegiatan dengan sungguh-sungguh jadi dapat dikatakan bahwa aktifitas siswa sangat aktif mengikuti pembelajaran dengan media.

Minat merupakan sumber motivasi yang mendorong orang untuk melakukan sesuatu, bila mereka melihat bahwa sesuatu itu menguntungkan, merekapun berminat. Ini kemudian mendatangkan kepuasan. Bila kepuasan berkuran, minatpun akan berkurang (Elizabet B Hurlock:114).

Begitu pula untuk belajar sangat diperlukan adanya minat dan motivasi. Motivation is an essential condition of learning (dalam buku Sardiman, 2010:84). Bahwa hasil belajar akan 
menjadi optimal, kalau ada motivasi dan motivasi dapat muncul apabila ada minat. Makin tepat motivasi yang diberikan, akan makin berhasil pula pelajaran itu.

Dalam pembelajaran senam lantai guling depan dengan permainan tiga pos berhasil menumbuhkan kepuasan dan motivasi dalam belajar. Ini dapat ditunjukan dari hasil pengisian angket kepuasan dan motivasi dalam belajar. Ini dapat ditunjukan dari hasil pegisian angket tanggapan siswa terhadap model pembelajaran senam lantai guling depan dengan permainan tiga pos termasuk positif. Ini ditunjukan dengan 100\% jawaban siswa setuju dan menyatakan siswa tertarik dan antusias mengikuti pembelajaran senam guling depan dengan permainan tiga pos. Hal ini menunjukkan bahwa siswa memberikan respon positif terhadap pembelajaran senam lantai sehingga siswa lebih berminat dan termotivasi untuk belajar lebih giat lagi. Jadi dapat disimpulkan bahwa pembelajaran senam lantai guling depan dengan permainan tiga pos dapat meningkatkan hasil belajar siswa.

\section{SIMPULAN}

Berdasarkan analisis data dan pembahasan yang telah peneliti lakukan, maka dapat disimpulkan beberapa hal yang berkaitan dengan hipotesis penelitian secara khusus sebagai berikut.
1) Pembelajaran senam lantai guling depan dengan menggunakan permainan tiga pos memiliki dampak positif dalam meningkatkan hasil belajar siswa yang ditandai dengan peningkatan ketuntasan belajar siswa kelas V dalan setiap siklus, yaitu siklus I dan siklus II.

2) Pembelajaran senam lantai guling depan dengan menggunakan metode bermain mempunyai pengaruh positif, yaitu meningkatkan minat dan motivasi belajar yang ditujukan dengan rata-rata jawaban siswa yang menyatakan bahwa siswa tertarik dan berminat dengan metode pembelajaran tersebut sehingga mereka menjadi suka dan termotivasi untuk belajar. Ini ditujukan dengan $100 \%$ pada angket motivasi dan $100 \%$ pada angket minat menjawab setuju dengan pembelajaran permainan pada senam lantai guling depan sehingga dapat disimpulkan bahwa dengan media bermain dalam pembelajaran senam lantai guling depan dengan permainan tiga pos bisa meningkatkan hasil belajar.

\section{DAFTAR PUSTAKA}

\section{Anni. 2004. Aktivitas Belajar dan}

Pembelajaran Siswa. Bandung: PT Refika Aditama 
Jurnal Pendidikan Jasmani Kesehatan dan Rekreasi (Penjaskesrek)

Volume 8, Nomor 1, Januari 2021

Aqib Zainal. 2006. Profesional guru dalam

pembelajaran, Surabaya: Cendekia

Nasution. 2004. Aktivitas Belajar Siswa.

Yogyakarta: Pustaka Pelajar

Sardiman. 2006. Aktivitas Pelajar Peserta

Pidik. Jakarta: Bumi Aksara

Sudjana. 2004. Hasil Belajar Peserta Didik.

Jakarta: PT Multi Kreasi Satudelapan 